\title{
Single cell protein production by Wickerhamomyces anomalus CCC32 using crude glycerol
}

\section{Produção de proteína unicelular por Wickerhamomyces anomalus CCC32 a partir de glicerol bruto}

\author{
Jucilene Pinto da Silva ${ }^{1}$; Gervásio Paulo da Silva ${ }^{2}$; André Dias de Azevedo Neto ${ }^{3}$; \\ Marcia Luciana Cazetta ${ }^{4}$
}

\begin{abstract}
The objective of this work was to evaluate the production of single cell protein (SCP) by five yeasts using crude glycerol as carbon source, to select the most promising strain and optimize biomass and crude protein production by central composite design (CCD). Wickerhamomyces anomalus CCC32 was the most promising strain for SCP production with biomass production of $20 \mathrm{~g} \mathrm{~L}^{-1}$ and crude protein concentration of $33 \%$ after $84 \mathrm{~h}$ using crude glycerol $25 \mathrm{~g} \mathrm{~L}^{-1}, \mathrm{NaNO}_{3} 3.5 \mathrm{~g} \mathrm{~L}^{-1}$ and $6.5 \mathrm{~g} \mathrm{~L}^{-1}$ of urea, at $30{ }^{\circ} \mathrm{C}$ and $150 \mathrm{rpm}$. Crude glycerol proved to be an excellent substrate option for SCP production, adding value to this residue. W. anomalus CCC32 showed promising characteristics for SCP production as fast growth and biomass production with high crude protein content.
\end{abstract}

Keywords: Agro industrial wastes. Fungi. Fermentation.

\section{Resumo}

O objetivo deste trabalho foi avaliar a produção de proteína microbiana, ou proteína unicelular, por cinco leveduras utilizando glicerol bruto como fonte de carbono, selecionar a cepa mais promissora e otimizar a produção de biomassa e proteína bruta por meio de delineamento composto central rotacional (DCCR). Wickerhamomyces anomalus CCC32 foi a cepa mais promissora para a produção de SCP, com produção de cerca de $20 \mathrm{~g} \mathrm{~L}^{-1}$ de biomassa e concentração de proteína bruta de $33 \%$ após $84 \mathrm{~h}$ fermentação, utilizando $25 \mathrm{~g} \mathrm{~L}^{-1}$ de glicerol bruto, $3,5 \mathrm{~g} / \mathrm{L}^{-1}$ de $\mathrm{NaNO}_{3}$ e $6,5 \mathrm{~g} \mathrm{~L}^{-1}$ de ureia, a $30{ }^{\circ} \mathrm{C}$ e $150 \mathrm{rpm}$. O glicerol bruto mostrou-se uma excelente opção de substrato para a produção de SCP, sendo uma alternativa para agregar valor a esse resíduo. W. anomalus CCC32 apresentou características favoráveis à produção de SCP como crescimento rápido e produção de biomassa com elevado teor de proteína bruta.

Palavras-chave: Resíduo agroindustrial. Fungo. Fermentação.

\footnotetext{
${ }^{1}$ Me. em Microbiologia Agrícola, UFRB, Cruz das Almas, Bahia, Brasil. E-mail: jucilene.cf@ hotmail.com

2 Prof. Dr., Dpto de Educação, UNEB, Senhor do Bonfim, Bahia. Brasil. E-mail: gpsilva@ uneb.br

3 Prof. Dr., Centro de Ciências Exatas e Tecnológicas, UFRB, Cruz das Almas, Bahia, Brasil. E-mail: andre@ufrb.edu.br

${ }^{4}$ Profa. Dra., Centro de Ciências Exatas e Tecnológicas, UFRB, Cruz das Almas, Bahia, Brasil. E-mail: malucz@ufrb.edu.br
} 


\section{Introduction}

Single cell protein (SCP) refers to the dried cells of microorganisms such as yeast, filamentous fungi, algae and bacteria which can be used as a protein sources for human and animal food (SISMAN et al., 2012; NAJAFPOUR, 2015). SCP has many applications in the food industry because of their high protein content, high percentage of essential amino acids, vitamins and other nutrients such as mineral salts (ANAPUMA; RAVINDRA, 2000; GAO et al., 2007; WANG et al., 2009). Thus, it can substitute conventional protein sources like soybean and fish meal (ANAPUMA; RAVINDRA, 2000), having a promising biotechnological application, which is even more advantageous when produced using agro industrial residues as substrates (PONSANO et al., 2003).

Some yeasts like Saccharomyces cerevisiae, Candida utilis, C. tropicalis, Cryptococcus aureus and some species of the genus Hansenula, Pichia and Torulopsis can be used for SCP production. Their biomass has high levels of protein, besides being a source of complex B vitamins, minerals and other components that stimulate resistance to diseases when used feeding for marine animals (ZHENMING et al., 2006). S. cerevisiae in addition to having high crude protein content, shows similar amino acid profile to those described in fish meal and can be used in aquaculture (VIDAKOVIC et al., 2015). According Juszczyk et al. (2013) the biomass formed by the strain Yarrowia lipolytica S6 produced in crude glycerol as carbon source, exhibited high crude protein concentration $(42-45 \%)$ and essential amino acids such as lysine, threonine and phenylalanine which can be used as a high quality nutritional component for animal feed.

SCP production from agro-industrial wastes makes this process economically attractive, as it reduces production costs and contributes to recycle wastes (ANAPUMA; RAVINDRA, 2000; SISMAN et al., 2012). Several substrates are used for SCP production, such as sugarcane molasses, whey, beet vinasse and crude glycerol, among others (RITALA et al., 2017). Crude glycerol, a by-product generated from biodiesel production in a proportion of $10 \%(\mathrm{v} / \mathrm{v})$, consists of glycerol, salts (such as potassium and sodium) and residual alcohol (methanol or ethanol) (da SILVA et al., 2015). Crude glycerol can be refined obtaining pure glycerol, which is widely used in the pharmaceutical and cosmetic industries (GALANAKIS, 2012; UPRETY et al., 2016). However, the refining process consumes a lot of energy and has high cost, making this process impracticable for small and medium producers of biodiesel (UPRETY et al., 2016). On the other hand, its disposal requires adequate treatment, as it can impact the environment, generating additional costs to the biodiesel production chain (LUO et al., 2016). Therefore, the development of processes to convert low-cost crude glycerol into industrial products is desirable, since it may be an alternative for its biotechnological enhancement; besides adding value to the biodiesel production chain (YANG $e t$ al., 2012).

Crude glycerol has advantages over other substrates, such as its lower cost and large availability, and can be used substituting traditional carbohydrates such as sucrose, glucose and starch to obtain value-added products such as high-gross-rate microbial biomass (PAPANIKOLAOU et al., 2008; QUIN et al., 2017). The objective of this work was to evaluate the production of yeast SCP using crude glycerol as a carbon source, in order to select the most promising yeast and to optimize the production of biomass and crude protein.

\section{Material and methods}

\section{Microorganisms and substrate}

Yeasts Candida (Metschnikowia) pseudointermedia CAC01, Rhodotorula mucilaginosa CCC31, Wickerhamomyces anomalus CCC32, Aureobasidium pullulans EBJ31 and Trichosporon asahii EPB13 belong to the collection of cultures of the Laboratory of Biotechnology of Microorganisms from the State University of Bahia - Campus Senhor do Bomfim, Bahia, Brazil. C. (Metschnikowia) pseudointermedia $\mathrm{CAC} 01$ was isolated from contaminated commercial coconut water (latitude $10^{\circ} 28^{\prime \prime} 15^{\prime} \mathrm{S}$ and $40^{\circ}$ $\left.10^{\prime \prime} 12^{\prime} \mathrm{W}\right) . R$. mucilaginosa CCC31 and W. anomalus CCC32 were isolated from cochineal (Dactylopius sp.) on leaves of the ornamental plant Ardisia crenata ("cafezinho") (Both latitude 10 28" 15.9' $\mathrm{S}$ and longitude $40^{\circ}$ $\left.10^{\prime \prime} 12 \mathrm{~W}\right)$. A. pullulans EBJ31 and T. asahii EPB13 were isolated from soil containing organic material such as decaying vegetables and goat droppings. (latitude $10^{\circ} 12^{\prime \prime}$ 53.3' $\mathrm{S}$ and longitude $40^{\circ} 12^{\prime \prime} 59.8^{\prime} \mathrm{W}$ ). The strains were maintained in glycerol P.A $40 \%(\mathrm{p} / \mathrm{v})$ at $-18{ }^{\circ} \mathrm{C}$ for preservation. The crude glycerol used in the experiments was composed of $81 \%$ glycerol $(\mathrm{p} / \mathrm{v})$ and was obtained from a biodiesel plant located in the city of Candeias, Bahia, Brazil. 


\section{Fermentative assays}

The fermentative and inoculum media were prepared using Malt extract (ME) modified containing $\left(\mathrm{g} \mathrm{L}^{-1}\right)$ : yeast extract (3.0), malt extract (3.0), peptone (5.0) and crude glycerol (20.0). Yeasts were cultured in $50 \mathrm{~mL}$ medium, agitated at $150 \mathrm{rpm}, 30{ }^{\circ} \mathrm{C}$, during $24 \mathrm{~h}$ to obtain the inoculum. Then, $10 \%$ of the inoculum was transferred into $125 \mathrm{~mL}$ Erlenmeyer-flasks containing $25 \mathrm{~mL}$ of medium, $\mathrm{pH} 5.0$, adjusted with $2 \mathrm{M} \mathrm{HCl}$. The flasks were incubated in shaker at $30{ }^{\circ} \mathrm{C}$ and $150 \mathrm{rpm}$ for $96 \mathrm{~h}$ and samples were taken every $24 \mathrm{~h}$.

\section{Evaluation of different nitrogen sources for biomass and crude protein production}

To test the influence of different nitrogen sources on the selected yeast was a medium containing $\left(\mathrm{g} \mathrm{L}^{-1}\right): \mathrm{K}_{2}$ $\mathrm{HPO}_{4}(1.0), \mathrm{NaCl}(1.0), \mathrm{MgSO}_{4}(0.2)$, crude glycerol (20.0) and different nitrogen sources at $10 \mathrm{~g} \mathrm{~L}^{-1}$ : yeast extract, corn steep liquor, peptone, sodium nitrate (NaNO3), ammonium sulfate $\left(\left(\mathrm{NH}_{4}\right)_{2} \mathrm{SO}_{4}\right)$ and urea $\left(\mathrm{CH}_{4} \mathrm{~N}_{2} \mathrm{O}\right)$ was used. The fermentation assays occurred in $250 \mathrm{~mL}$ Erlenmeyer-flasks containing $50 \mathrm{~mL}$ of medium, at 150 $\mathrm{rpm}, 30^{\circ} \mathrm{C}$ during $24 \mathrm{~h}$. All the tests were performed in triplicate and the results obtained were statistically evaluated by analysis of variance (ANOVA) and Tukey's test at $5 \%$ of probability using the software R studio 3.3.4.

\section{Analytical methods}

The samples were centrifuged at $5.000 \mathrm{rpm}$ for $20 \mathrm{~min}$ and the biomass was used to determine cell growth and crude protein content; the supernatant was frozen for further analysis of glycerol and alcohol by High Performance Liquid Chromatography (HPLC, Dionex model Ultimate 3000, Germany) equipped with RI detector and Rezex ROA H+ column (300 x $7.8 \mathrm{~mm})$. The temperature was kept up at $80{ }^{\circ} \mathrm{C}$ and mobile phase of $\mathrm{H}_{2} \mathrm{SO}_{4} 0.005 \mathrm{M}$

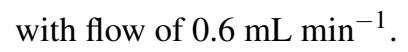

Cellular growth $\left(\mathrm{g} \mathrm{L}^{-1}\right)$ was determined using standard curve relating dry mass $\mathrm{x}$ optical density at $600 \mathrm{~nm}$. To determine the crude protein concentration, the biomass was washed with distilled water and dried at $65^{\circ} \mathrm{C}$. Then, $0.1 \mathrm{~g}$ of the dried biomass was digested with a mixture of $3.5 \mathrm{~mL}$ concentrated sulfuric acid and $3.0 \mathrm{~mL}$ hydrogen peroxide $30 \%(\mathrm{v} / \mathrm{v})$ at $350{ }^{\circ} \mathrm{C}$ for $1.5 \mathrm{~h}$. The total protein content of the biomass was determined by the phenolhypochlorite method, adopting the factor of 6.25 for the conversion from the total nitrogen contents (WEATHERBURN, 1967; FELKER, 1977).
Optimization of biomass and crude protein production using Central Composite Design (CCD)

The optimization of biomass and crude protein production was performed using the response surface methodology. Biomass $\left(\mathrm{g} \mathrm{L}^{-1}\right)$ and crude protein production (\%) were dependent variables and the crude glycerol, sodium nitrate and urea were independent variables. A complete factorial planning matrix $2^{3}$ was constructed by means of Central Composite Design (CCD), totalizing 17 assays (RODRIGUES; IEMMA, 2009). Two levels were selected, one higher (+1) and an inferior one (-1), in addition to two axial points $(+1.68$ and -1.68$)$ and a central point $(0)$ which was performed in triplicate. This model is represented by a second-order polynomial regression, given by equation (1)

$$
\begin{array}{r}
Y=b_{0}+b_{1} X_{1}+b_{2} X_{2}+b_{3} X_{3}+b_{12} X_{1} X_{2}+b_{13} X_{1} X_{3} \\
+b_{23} X_{2} X_{3}+b_{11} X_{1}^{2}+b_{22} X_{2}^{2}+b_{33} X_{3}^{2}
\end{array}
$$

where $Y$ is the predicted response of biomass production and/or crude protein production; $X_{1}, X_{2}$ and $X_{3}$ are the coded forms (glycerol, sodium nitrate and urea, respectively); $b_{0}$ refers to the point of intersection; $b_{1}, b_{2}$ and $b_{3}$ are linear coefficients; $b_{12}$ coefficient of double interaction; $b_{11}, b_{22}$ and $b_{33}$ are quadratic coefficients. The values of the studied levels were calculated through equation (2)

$$
X_{n}=\frac{X-X_{0}}{X_{+1}-X_{-1}},
$$

where $X_{n}$ is the encoded value; $X$ is the real value of the independent variable; $X_{0}$ is the actual value of the center point; $X_{+1}$, is the value of the upper level; $X_{-1}$ is the value of the lower level.

The inoculum used in the experimental design trials was prepared in $125 \mathrm{~mL}$ Erlenmeyer-flasks containing $25 \mathrm{~mL}$ of $\left(\mathrm{g} \mathrm{L}^{-1}\right)$ : K2HPO4 (1.0), $\mathrm{NaCl}$ (1.0), $\mathrm{MgSO}_{4}(0.2)$, yeast extract (1.0), $\mathrm{NaNO}_{3}$ (5.0), urea (5.0) and crude glycerol (20.0), at $150 \mathrm{rpm}, 30{ }^{\circ} \mathrm{C}$, for $24 \mathrm{~h}$. The fermentative assays were carried out in 250 $\mathrm{mL}$ Erlenmeyer-flasks containing $50 \mathrm{~mL}$ of the composition media described above and $10 \%$ (v/v) inoculum, incubated in shaker under the same conditions. The concentration of crude glycerol, sodium nitrate and urea were adjusted according to each experimental design to be presented in Table 2. The results were evaluated using the software Statistic 7.1. 


\section{Results and discussion}

Evaluation of biomass and crude protein production using crude glycerol

The kinetic of crude glycerol fermentation by yeast evaluated for $96 \mathrm{~h}$ is shown in Figure 1. The yeast $W$. anomalus CCC32 consumed the entire substrate in less than 48 h, followed by A. pullulans EBJ31 and C. pseudointermedia CAC01 (72 h); R. mucilaginosa CCC31 consumed crude glycerol after $96 \mathrm{~h}$ and T. asahii EPB13 did not use glycerol.

The strain $W$. anomalus CCC32 reached the highest biomass production, of around $21.5 \mathrm{~g} \mathrm{~L}^{-1}$, after $72 \mathrm{~h}$; strains A. pullulans EBJ31, C. pseudointermedia CAC01 and $R$. mucilaginosa CCC31 produced less biomass and showed slowercellular growth, probably due to the slower consumption of glycerol; T. asahii EPB13 was the strain that ehxibited the lowest biomass production $\left(5.24 \mathrm{~g} \mathrm{~L}^{-1}\right)$, suggesting that it growth using other nutrients from culture medium than glycerol.

The maximum crude protein production occurred after $24 \mathrm{~h}$ for all strains and there was no statistical difference ( $p>0.05$ ) between A. pullulans EBJ31, $C$. (Metschnikowia) pseudointermedia CAC01 and W. anomalus CCC32. However, after $24 \mathrm{~h} \mathrm{~W}$. anomalus CCC32 produced approximately twice as much biomass $(12.97 \mathrm{~g}$ $\left.\mathrm{L}^{-1}\right)$, statistically differing from other strains $(p<0.05)$, which resulted in a higher yield of protein production $\left(\mathrm{Y}_{\mathrm{p} / \mathrm{s}}\right), 0.05 \mathrm{~g} \mathrm{~g}^{-1}$.

Considering that $W$. anomalus CCC32 ehxibited fast growth in medium containing crude glycerol, higher biomass production, faster glycerol consumption and higher protein yield, it was the strain selected for the biomass optimization and crude protein production tests.

Yeast W. anomalus shows several biotechnological interest and industrial applications, as for biological control in fruits (OLSTORPE et al., 2010; ORO et al., 2014; CAPPELLI et al., 2014), production of biofuels (WALKER, 2011), polyhydroxyalcanoates (OJHAA; DAS, 2018), biosurfactants (SOUZA et al., 2018), aromatic and sensory compounds that improve the taste of foods such as cocoa and chocolate (KONÉ et al., 2016), beer (BASSO et al., 2016), oriental foods (ZHA et al., 2018), among others. In addition, this yeast is classified as biosafety level 1, which makes it safe for many different industrial applications (SUNDH; MELIN, 2010).
Nitrogen sources for SCP production by W. anomalus CCC 32

In addition to the carbon source, the production of biomass and protein depends on the specific characteristics of each strain and its ability to assimilate different carbon and nitrogen sources. Therefore, it is common to observe high protein production in yeast biomass using different nitrogen sources. Li et al. (2017) reported that ammonia, urea, peptone, yeast extract, corn steep liquor, among others, increased yeast cell growth, but not all sources contributed in a similar way for each species. In the case of $W$. anomalus CCC32 strain the yeast extract led to the higher production of biomass and crude protein, differing statistically from other nitrogen sources $(p<0,05)$, see Table 1, as described by Gao et al. (2007) and Gao et al. (2012) for production of SCP by Cryptococcus aureus $\mathrm{G} 7 \mathrm{a}$ and Candida tropicalis, respectively. The yeast extract contains vitamins, minerals and amino acids that promote cell growth (LI et al., 2011). However, sodium nitrate also favored the production of biomass, not differing statistically from peptone $(p>0.05)$. On the other hand, urea favored the production of crude protein, whith $32.5 \%$, and $4.54 \mathrm{~g} \mathrm{~L}^{-1}$ biomass. Patelski et al. (2015) reported that combination of urea and dibasic phosphate increased production of crude protein by Candida tropicalis and Trichosporon cutaneaum, while for protein production was favored by urea as the only nitrogen source for $S$. cerevisiae. Therefore, according to these authors, the nitrogen source must be carefully chosen because it influences both quantitatively and qualitatively the production of protein.

Table 1 - Biomass $\left(\mathrm{g} \mathrm{L}^{-1}\right)$ and crude protein $(\%)$ production by $W$. anomalus CCC 32 after $24 \mathrm{~h}$ fermentation in different nitrogen sources.

\begin{tabular}{ccc}
\hline Nitrogen source & $\begin{array}{c}\text { Biomass } \\
\left(\mathbf{g ~ L}^{-1}\right)\end{array}$ & $\begin{array}{c}\text { Crude protein } \\
(\mathbf{\%})\end{array}$ \\
\hline Yeast extract & $11.65^{a *}$ & $37.33^{a}$ \\
Sodium nitrate & $10.37^{b}$ & $22.67^{e}$ \\
Peptone & $10.18^{b}$ & $29.67^{c}$ \\
Corn steep liquor & $6.75^{c}$ & $13.33^{f}$ \\
Ammonium sulfate & $6.13^{d}$ & $26.67^{d}$ \\
Urea & $4.54^{e}$ & $32.50^{b}$ \\
\hline
\end{tabular}

*Equal letters do not differ according Scott-Knott's test at 5\% significance

Source: The authors. 
Figure 1 - Kinetic fermentation of crude glycerol by W. anomalus CCC32 (A), A. pullulans EBJ31 (B), C. (Metschnikowia) pseudointermedia CAC01 (C), R. mucilaginosa $\mathrm{CCC} 31$ (D) and T. asahii EPB13 (E) at $30{ }^{\circ} \mathrm{C}$, $150 \mathrm{rpm}$, during $96 \mathrm{~h}$.
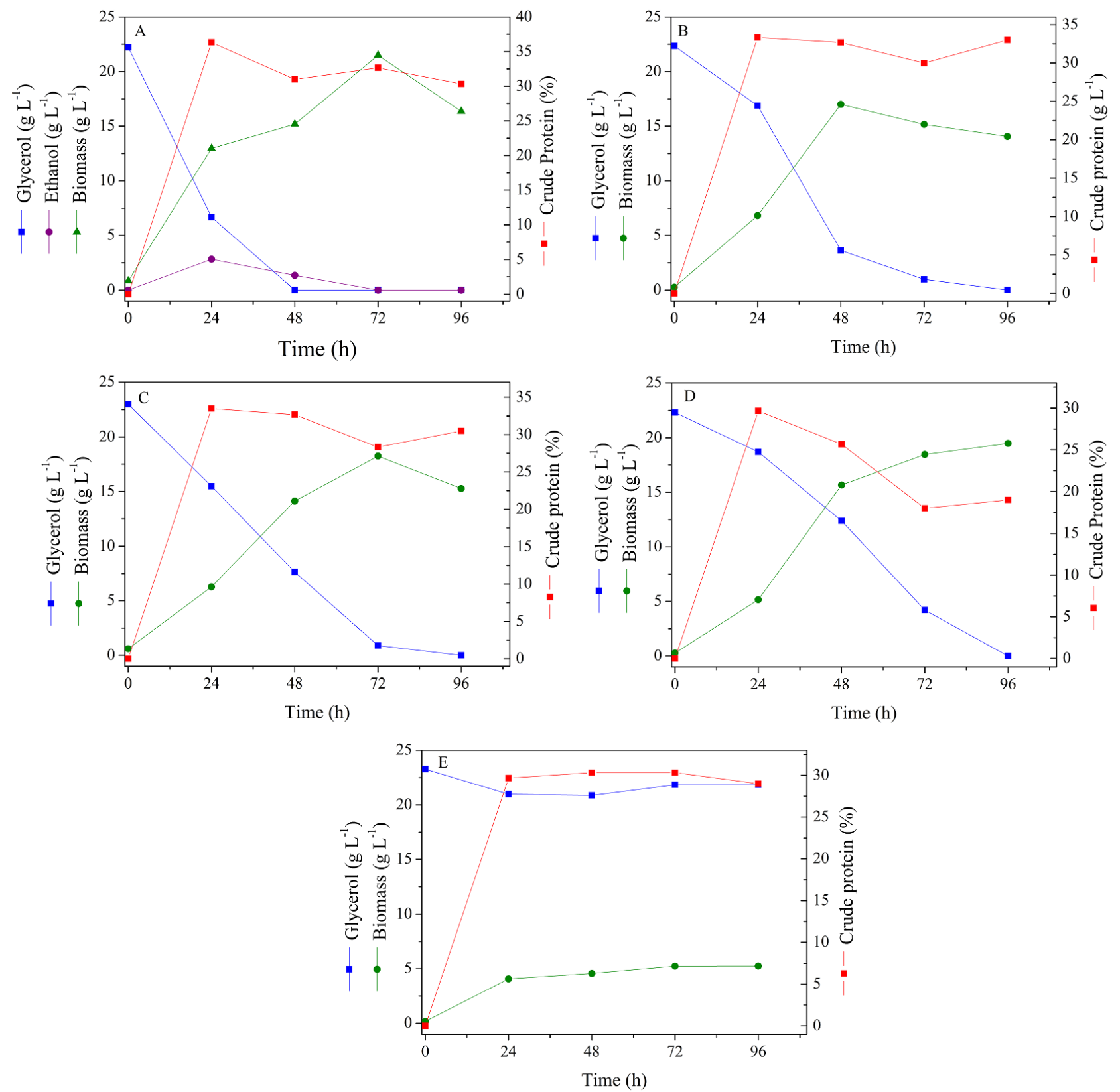

Source: The authors.

Highest SCP production by W. anomalus CCC32 occurred with the yeast extract, however sodium nitrate and urea also showed good results. While sodium nitrate favored the production of biomass, urea favored the production of crude protein. Thus, due to the high commercial cost of yeast extract (and peptone which may increase the cost of SCP production, combinations of sodium nitrate and urea were chosen as nitrogen sources for the following fermentation tests.
Ali et al. (2009) and Ahmed et al. (2010) also reported that urea favored the production of crude protein in yeasts. Gao et al. (2007) substituted the yeast extract by soybean meal hydrolyzate as nitrogen source in the SCP production by $C$. aureus $\mathrm{G} 7 \mathrm{a}$, since the use of low cost substrates is one of the most important aspects for SCP production. The use of yeast extract and peptone in large scale greatly increases the cost of production due to its high commercial value. 
Effect of crude glycerol and inorganic salts on biomass and crude protein production using Central Composite Design (CCD)

The results obtained in the CCD $2^{3}$ showed the influence of crude glycerol, urea and sodium nitrate on the biomass and crude protein production by $W$. anomalus CCC 32 after $24 \mathrm{~h}$ of fermentation, see Table 2 . The highest biomass production was obtained in the assay 7 (9.74 $\mathrm{g} \mathrm{L}^{-1}$ ) and the highest crude protein production in assays 1,5 and $8(30 \%)$.

According to the statistical analysis, crude glycerol and urea had a significant influence on biomass production, in the linear terms $(p<0.05)$. However, only crude glycerol had a significant influence on crude protein production, in the quadratic term, that is, the increase in glycerol concentrations significantly decreased crude protein production, Table 3.

High concentrations of the carbon source in the culture medium increase osmotic pressure and, consequently, reduce cell growth (BZDUCHA-WOROBEL et al., 2015). In addition, the presence of contaminants in the crude glycerol can negatively influence the results, which may explain the reduction of biomass production by $W$. anomalus $\mathrm{CCC} 32$ in the assays where crude glycerol concentration was above $28 \mathrm{~g} \mathrm{~L}^{-1}$. Kurcz et al. (2018) also reported a significant influence of glycerol concentration on biomass and crude protein production by Candida utilis. Dos Santos et al. (2012) observed the concentration of crude glycerol had significant effect only on the biomass production by Yarrowia lipolytica NRRL YB423 , but did not have a significant effect for crude protein production.

However, the analysis of variance showed that values of calculated $\mathrm{F}$ for biomass production and crude protein production were lower than the Ftab (3.68), although $\mathrm{R}^{2}$ was greater than 0.7 for both responses, Table 4.

Therefore, new tests were performed varying the concentrations of glycerol from 20 to $30 \mathrm{~g} \mathrm{~L}^{-1}$, setting the concentrations of $\mathrm{NaNO}_{3}\left(3.5 \mathrm{~g} \mathrm{~L}^{-1}\right)$ and urea $(6.5 \mathrm{~g}$ $\mathrm{L}^{-1}$ ) to confirm the values of biomass and crude protein production. The average crude protein production was 33\% for the different concentrations of crude glycerol, not differing statistically from each other. On the other hand, the biomass production was higher at a glycerol concentration $25 \mathrm{~g} \mathrm{~L}^{-1}$, reaching $9.34 \mathrm{~g} \mathrm{~L}^{-1}$, Table 5.
The fermentation kinetics was evaluated for $120 \mathrm{~h}$. There was little change in $\mathrm{pH}$ over time, which remained constant at around 6.0, evidencing the low production of organic acids by this strain and that most of the carbon was used to produce SCP, with little release of undesirable products from the metabolism to the culture medium. The maximum biomass production was around $20 \mathrm{~g} \mathrm{~L}^{-1}$ after $84 \mathrm{~h}$ of fermentation during the exponential phase, and the maximum crude protein yield was $33 \%$ on average between 12 and $36 \mathrm{~h}$, yield $\left(\mathrm{Y}_{\mathrm{x} / \mathrm{p}}\right)$ of $0.1 \mathrm{~g} \mathrm{~g}^{-1}$ and productivity $\left(\mathrm{Y}_{\mathrm{p}}\right)$ of $0.018 \mathrm{~g} \mathrm{~L}^{-1} \mathrm{~h}^{-1}$, Figure 2.

Figure 2 - Fermentation kinetics of biomass $\left(\mathrm{g} \mathrm{L}^{-1}\right)$ and crude protein (\%) production by $W$. anomalus $\mathrm{CCC} 32$ at crude glycerol $25 \mathrm{~g} \mathrm{~L}^{-1}, \mathrm{NaNO}_{3} 3.5 \mathrm{~g} \mathrm{~L}^{-1}$, urea $6.5 \mathrm{~g}$ $\mathrm{L}^{-1}$ at $30^{\circ} \mathrm{C}, 150 \mathrm{rpm}$ during $120 \mathrm{~h}$.

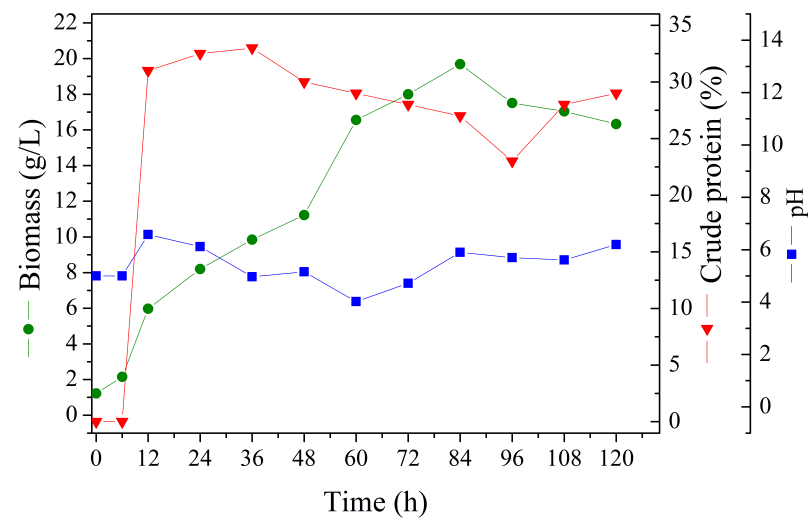

Source: The authors.

The results obtained with $W$. anomalus CCC32 in mineral medium as nitrogen sources, are comparable to those obtained by yeasts using high cost media such as yeast extract and peptone, which were among 17-22 $\mathrm{g} \mathrm{L}^{-1}$, on average (GALVANO et al., 2011; TACCARI et al., 2012; SANTOS et al., 2013). In addition, the mineral medium provided for $W$. anomalus $\mathrm{CCC} 32$ growth favored high biomass yield $\left(20 \mathrm{~g} \mathrm{~L}^{-1}\right)$ in about half the time when compared with other yeast strains. Duarte et al. (2013) and Uprety et al. (2017) described maximum biomass production by Candida sp. LEB-M3 (around 20g/L) and Rhodosporidium toruloides ATCC10788 (21.16 $\left.\mathrm{g} \mathrm{L}^{-1}\right)$ after $168 \mathrm{~h}$, respectively.

Crude protein production by $W$. anomalus CCC 32 were similar to those obtained by $C$. utilis $(36.7 \%)$ in medium containing potato wastewater and glycerol at 5\% (w/v) after $72 \mathrm{~h}$ (KURCZ et al. 2018). However, dos Santos et al. (2012) described lower crude protein content (18.2\%) by Y. lipolytica NRRL YB-423 using crude glycerol and ammonium sulfate as nitrogen source. 
Table 2 - Central composite design $2^{3}$ matrix showing codified values, real values and responses obtained for biomass and crude protein production.

\begin{tabular}{cccccc}
\hline Essays & $\begin{array}{c}\text { Glycerol } \\
\left(\mathbf{g ~ L}^{-1}\right)\end{array}$ & $\begin{array}{c}\mathbf{N a N O}_{3} \\
\left(\mathbf{g ~ L}^{-1}\right)\end{array}$ & $\begin{array}{c}\text { Urea } \\
\left(\mathbf{g ~ L}^{-1}\right)\end{array}$ & $\begin{array}{c}\text { Biomass } \\
\left(\mathbf{g ~ L ~}^{-1}\right)\end{array}$ & $\begin{array}{c}\text { Crude protein } \\
(\boldsymbol{\%})\end{array}$ \\
\hline 1 & $-1(28)$ & $-1(3.5)$ & $-1(3.5)$ & 8.60 & 30 \\
2 & $+1(52)$ & $-1(3.5)$ & $-1(3.5)$ & 8.08 & 26 \\
3 & $-1(28)$ & $+1(6.5)$ & $-1(3.5)$ & 8.17 & 28 \\
4 & $+1(52)$ & $+1(6.5)$ & $-1(3.5)$ & 7.70 & 28 \\
5 & $-1(28)$ & $-1(3.5)$ & $+1(6.5)$ & 9.34 & 30 \\
6 & $+(52)$ & $-1(3.5)$ & $+1(6.5)$ & 8.47 & 23 \\
7 & $-1(28)$ & $+1(6.5)$ & $+1(6.5)$ & 9.74 & 26 \\
8 & $+1(52)$ & $+1(6.5)$ & $+1(6.5)$ & 8.77 & 30 \\
9 & $-1.68(20)$ & $0(5.0)$ & $0(5)$. & 8.88 & 29 \\
10 & $+1.68(60)$ & $0(5.0)$ & $0(5.0)$ & 8.00 & 27 \\
11 & $0(40)$ & $-1.68(2.5)$ & $0(5.0)$ & 7.69 & 26 \\
12 & $0(40)$ & $+1.68(7.5)$ & $0(5.0)$ & 9.20 & 22 \\
13 & $0(40)$ & $0(5.0)$ & $-1.68(2.5)$ & 7.90 & 25 \\
14 & $0(40)$ & $0(5.0)$ & $+1.68(7.5)$ & 8.57 & 21 \\
15 & $0(40)$ & $0(5.0)$ & $0(5.0)$ & 8.77 & 24 \\
16 & $0(40)$ & $0(5.0)$ & $0(5.0)$ & 8.54 & 25 \\
17 & $0(40)$ & $0(5.0)$ & $0(5.0)$ & 8.54 & 23 \\
\hline
\end{tabular}

Source: The authors.

Table 3 - Regression coefficients for biomass and crude protein production by W. anomalus CCC32.

\begin{tabular}{cccccccccc}
\hline Factors & \multicolumn{2}{c}{ Regression coeficients } & \multicolumn{2}{c}{ Standard error } & \multicolumn{2}{c}{$\mathbf{t}(\mathbf{7})$} & \multicolumn{3}{c}{$p$-value } \\
\cline { 2 - 9 } & Biomass & Protein & Biomass & Protein & Biomass & Protein & Biomass & Protein \\
\hline Means & 8.60 & 23.83 & 0.24 & 1.37 & 35.75 & 17.37 & 0.000000 & 0.000001 \\
Glycerol (L) & -0.32 & -0.76 & 0.11 & 0.64 & -2.79 & -1.17 & $\mathbf{0 . 0 2 6 7 8 3}$ & 0.277173 \\
Glycerol (Q) & -0.01 & 1.98 & 0.12 & 0.70 & -0.06 & 2.80 & 0.957175 & $\mathbf{0 . 0 2 6 5 9 1}$ \\
$\mathrm{NaNO}_{3}(\mathrm{~L})$ & 0.18 & -0.27 & 0.11 & 0.64 & 1.57 & -0.42 & 0.159364 & 0.684452 \\
$\mathrm{NaNO}_{3}(\mathrm{Q})$ & -0.005 & 0.57 & 0.12 & 0.70 & -0.04 & 0.80 & 0.968106 & 0.448302 \\
Urea (L) & 0.36 & -0.71 & 0.11 & 0.64 & 3.17 & -1.1 & $\mathbf{0 . 0 1 5 6 3 0}$ & 0.305302 \\
Urea (Q) & -0.07 & 0.21 & 0.12 & 0.70 & -0.63 & 0.30 & 0.543472 & 0.769702 \\
Glycerol x NaNO & -0.006 & 1.87 & 0.15 & 0.84 & -0.04 & 2.22 & 0.967411 & 0.061125 \\
$\mathrm{Glycerol} \mathrm{x} \mathrm{Urea}$ & -0.106 & 0.12 & 0.15 & 0.84 & -0.71 & 0.14 & 0.495000 & 0.886096 \\
$\mathrm{NaNO}_{3}$ x Urea & 0.19 & 0.37 & 0.15 & 0.84 & 1.27 & 0.44 & 0.41787 & 0.669302 \\
\hline
\end{tabular}

Source: The authors.

Table 4 - ANOVA for the regression model obtained by the response surface.

\begin{tabular}{ccccccccc}
\hline \multirow{2}{*}{ Factors } & \multicolumn{2}{c}{ Sum of squares } & \multicolumn{2}{c}{ df } & \multicolumn{2}{c}{ Mean square } & \multicolumn{2}{c}{ Fcal } \\
\cline { 2 - 8 } & Biomass & Protein & Biomass & Protein & Biomass & Protein & Biomass & Protein \\
\hline Regression & 4.01 & 91.29 & 9 & 9 & 0.44 & 10.14 & 2.6 & 1.79 \\
Residual & 1.21 & 39.65 & 7 & 7 & 0.17 & 5.66 & & \\
Total & 5.22 & 130.94 & 16 & 16 & & & & \\
\hline
\end{tabular}

Source: The authors. 
Table 5 - Biomass $\left(\mathrm{g} \mathrm{L}^{-1}\right)$ and crude protein $(\%)$ production by $W$. anomalus CCC32 in different glycerol concentrations, $150 \mathrm{rpm}, 30^{\circ} \mathrm{C}$ for $24 \mathrm{~h}$.

\begin{tabular}{ccc}
\hline $\begin{array}{c}\text { Crude glycerol } \\
\left(\mathbf{g ~ L ~}^{-1}\right)\end{array}$ & $\begin{array}{c}\text { Biomass } \\
\left(\mathbf{g ~ L}^{-1}\right)\end{array}$ & $\begin{array}{c}\text { Crude protein } \\
(\boldsymbol{\%})\end{array}$ \\
\hline 20.0 & $8.43^{b c}$ & $31.0^{a b}$ \\
22.5 & $8.35^{c}$ & $30.0^{b}$ \\
25.0 & $9.34^{a}$ & $33.0^{a}$ \\
27.5 & $8.7^{b c}$ & $30.0^{a b}$ \\
30.0 & $8.97^{a b}$ & $31.3^{a b}$ \\
\hline
\end{tabular}

*Equal letters at the same column do not differ according Tukeys test at $5 \%$ significance.

Source: The authors.

\section{Conclusion}

Almost all the yeasts studied in this work ehxibited good growth rates and SCP production, evidencing that crude glycerol can be used as a carbon source for biomass production. Besides, W. anomalus CCC32 was the strain that showed the best characteristics for production of SCP from crude glycerol as fast growth and production of biomass with high protein content a short time period. The production of biomass and crude protein in mineral medium has shown to be promising for SCP production, which can make the process economically more advantageous. The conversion of crude glycerol into higher value-added products, such as SCP, is important for the valorization and biotechnological application of this byproduct from biodiesel industry.

\section{Acknowledgments}

To the Coordenação de Aperfeiçoamento de Pessoal de Nível Superior (CAPES) for the scholarship, the Fundação Apoio à Pesquisa do Estado da Bahia (FAPESB) for financial support and Universidade do Estado da Bahia (UNEB).

\section{References}

AHMED, S.; AHMAD, F.; HASHMI, A. B. Production of microbial biomass protein by sequential culture fermentation of Arachniotus sp., and Candida utilis. Pakistan Journal Botany, Karachi, v. 42, p. 1225-1234, 2010.
ALI, S.; AHMED, S.; SHEIKH, M. A.; HASHMI, S. A.; RAJOKA, M. B.; JAMIL, A. Lysine production by Lhomoserine resistant mutant of Brevibacterium flavum. Journal of The Chemical Society of Pakistan, Pakistan, v. 32, p. 97-91, 2009.

ANAPUMA; RAVINDRA, P. Value-added food: single cell protein. Bioresource Technology, New Yourk, v. 18, p. 459-479, 2000. Doi: <https://doi.org/10.1016/ S0734-9750(00)00045-8>

BZDUCHA-WROBEL, A.; BŁAZEJAK, S.; MOLENDA, M.; RECZEK, L. Biosynthesis of $\beta(1,3) /(1,6)-$ glucans of cell wall of the yeast Candida utilis ATCC 9950 strains in the culture media supplemented with deproteinated potato juice water and glycerol. European Food Research Technology, Berlin, v. 240, n. 5, p. 1023-1034, 2015. Doi: <https://doi.org/10.1007/ s00217-014-2406-6>

BASSO, R. F.; ALCARDE, A. R.; PORTUGAL, C. B. Could non-Saccharomyces yeasts contribute on innovative brewing fermentations?. Food Research International, Barking, v. 86, p. 112-120, 2006. Doi: <https://doi.org/10. 1016/j.foodres.2016.06.002>

CAPPELLI, A.; ULISSI, U.; VALZANO, M.; DAMIANI, C.; EPIS, S.; GABRIELLI, M. G.; CONTI, S.; POLONELLI, L.; BANDI, C.; FAVIA, G.; RICCI, I. A Wickerhamomyces anomalus killer strain in the Malaria vector Anopheles stephensi. Plos One, San Francisco, v. 9, p. 1-9, 2014. Doi: <https://doi.org/10.1371/journal.pone. 0095988>

DUARTE, S.H.; GHISELLI, G.; MAUGERI, F. Influence of culture conditions on lipid production by Candida sp. LEB-M3 using glycerol from biodiesel synthesis. Biocatalysis and Agricultural Biotechnology, v. 2, p. 339-343, 2013. Doi: <https://doi.org/10.1016/j.bcab.2013.07.001>

FELKER, P. Microdetermination of nitrogen in seed protein extracts. Analytical Chemistry, Amsterdam, p. 49, v. 1080-1080, 1977. Doi: <https://doi.org/10.1021/ ac50015a053>

GALANAKIS, C. M. Recovery of high components from food wastes: conventional, emerging technologies and commercialized applications. Trends in Food Science Technology, Cambridge, v. 26, p. 68-87, 2012. Doi: <https://doi.org/10.1016/j.tifs.2012.03.003> 
GALVAGNO, M. A.; IANNONE, L. J.; BIANCHI, J.; KRONBERG, F.; ROST, E.; CARSTENS, M. R.; CERRUTTI, P. Optimization of biomass production of a mutant of Yarrowia lipolytica with an increased lipase activity using raw glycerol. Revista Argentina de Microbiologia, Buenos Aires, v. 43, p. 218-225, 2011. Doi: <https://doi.org/10.1590/S032575412011000300010.>

GAO, L.; CHI, Z.; SHENG, J.; NI, X.; WANG, L. Singlecell protein production from Jerusalem artichoke extract by a recently isolated marine yeast Cryptococcus aureus $\mathrm{G} 7 \mathrm{a}$ and its nutritive analysis. Applied Microbiology Biotechnology, Berlin, v. 77, p. 825-832, 2007. Doi: $<$ https://doi.org/10.1007/s00253-007-1210-7.>

GAO, Y.; LI, D.; LIU, Y. Production of single cell protein from soy molasses using Candida tropicalis. Annals of Microbiology, Milano, v. 62, p. 1165-1172, 2012. Doi: <https://doi.org/10.1007/s13213-011-0356-9>

JUSZCZYK, P.; TOMASZEWSKA, L.; KITA, A.; RYMOWICZ, W. Biomass production by novel strains of Yarrowia lipolytica using raw glycerol, derived from biodiesel production. Bioresourcce Technology, Amsterdam, v. 137, p. 124-131, 2013. Doi: <https://doi.org/10. 1016/j.biortech.2013.03.010>

KONÉ, M. K.; GUÉHI, S. T.; DURAND, N.; BANKOFFI, L.; BERTHIOT, L.; TACHON, A. F.; BROU, K.; BOULANGER, R.; MONTET, D. Contribution of predominant yeasts to the occurrence of aroma compounds during cocoa bean fermentation. Food Research International, Ottawa, v. 89, p. 910-917, 2016. Doi: <https: //doi.org/10.1016/j.foodres.2016.04.010>

KURCZ, A.; BŁAZEJAK, S.; KOT, A. M.; BZDUCHAWROBEL, A.; KIELISZEK, M. Application of industrial wastes for the production of microbial Single-Cell Protein by fodder yeast Candida utilis. Waste and Biomass Valorization, Netherlands, v. 9, p. 57-64, 2018. Doi: <https: //doi.org/10.1007/s12649-016-9782-z>

LI, M.; LIAO, X.; ZHANG, D.; DU, G.; CHEN, J. Yeast extract promotes cell growth and induces production of polyvinyl alcohol-degrading enzymes. Enzyme Research, New York, v. 2011, p. 1-8, 2011. Doi: <https://doi.org/10. 4061/2011/179819>

LI, Z.; WANG, D.; SHI, Y.C. Effects of nitrogen source on ethanol production in very high gravity fermentation of corn starch. Journal of Taiwan Institute Chemical Engineers, Amsterdam, v. 70, p. 229-235, 2017. Doi: <https://doi.org/10.1016/j.jtice.2016.10.055>
LUO, X.; GE, X.; CUI, S.; LI, Y. Value-added processing of crude glycerol into chemicals and polymers. Bioresource Technology, Barking, v. 215, p. 144-154, 2016. Doi: <https://doi.org/10.1016/j.biortech.2016.03.042>

NAJAFPOUR, G. D. Single cell protein. In: NAJAFPOUR, G. D. Biochemical engineering and biotechnology. 2. ed. Nova York: Elsevier Science, 2015. p. $417-434$

OJHAA, N.; DAS, N. A Statistical approach to optimize the production of polyhydroxyalkanoates from Wickerhamomyces anomalus VIT-NN01 using response surface methodology. International Journal of Biology Macromolecules, Colorado, v. 107, p. 2157-2170, 2018. Doi: <https://doi.org/10.1016/j.ijbiomac.2017.10.089>

OLSTORPE, M.; BORLING, J.; SCHNÜRER, J.; PASSOTH, V. Pichia anomala yeast improves feed hygiene during storage of moist crimped barley grain under Swedish farm conditions. Animal Feed Science Technology, Amsterdam, v. 156, p. 47-56, 2010. Doi: <https://doi.org/10.1016/j.anifeedsci.2009.12.008>

ORO, L.; ERICA, F.; CIANIA, M.; ROMANAZZIB, G.; COMITINIA, F. Biocontrol of postharvest brown rot of sweet cherries by Saccharomyces cerevisiae Disva 599, Metschnikowia pulcherrima Disva 267 and Wickerhamomyces anomalus Disva 2 strains. Postharvest Biology and Technology, Amsterdam, v. 96, p. 64-68, 2014. Doi: <https://doi.org/10.1016/j. postharvbio.2014.05.011>

PAPANIKOLAOU, S.; FAKAS, S.; FICK, M.; CHEVALOT, I.; GALIOTOU-PANAYOTOU, M.; KOMAITIS, M.; IVAN MARC, I.; AGGELIS, G. Biotechnological valorization of raw glycerol discharged after biodiesel (fatty acid methyl esters) manufacturing process: production of 1,3-propanediol, citric acid and single cell oil. Biomass and Bionergy, Oxford, v. 32, p. 60-71, 2008. Doi: <https://doi.org/10.1016/j.biombioe.2007.06.007>

PATELSKI， P.; BERLOWSKA， J.; DZIUGAN， P; PIELECH-PRZYBYLSKA， K.; BALCEREK， M.; DZIEKONSKA, U.; KALINOWSKA, H. Utilization of sugar beet bagasse for the biosynthesis of yeast SCP. Journal of Food Engineering, Essex, v. 167, p. 32-37, 2015. Doi: <https://doi.org/10.1016/j.jfoodeng.2015.03.031> 
PONSANO, E. H. G.; LACAVA, P. M.; PINTO, M. F. Chemical composition of Rhodocyclus gelatinosus biomass produced in poultry slaughterhouse wastewater. Brazilian Archives of Biology and Technology, $\mathrm{Cu}-$ ritiba, v. 46, p. 143-147, 2003. https://doi: 143-147. Doi: <https://doi.org/10.1590/S1516-89132003000200001>

QIN, L.; LIU, L.; ZENG, A-P.; WEI, D. From low-cost substrates to single cell oils synthesized by oleaginous yeasts. Bioresource Technology, Barking, v. 245, p. 1507 1519, 2017. Doi: <https://doi.org/10.1016/j.biortech.2017. $05.163>$

RODRIGUES, M. I.; IEMMA, A. F. Planejamento de experimentos e otimização de processos. 2. ed. Brasil: Cárita, 2009

RITALA, A.; RITALA, A.; HÄKKINEN, S. T.; TOIVARI, M.; WIEBE, M. G. Single cell protein-state-of-the-art, industrial landscape and patents 2001-2016. Frontiers in Microbiology, Lausanne, v. 8, p. 1-18, 2016. Doi: <https: //doi.org/10.3389/fmicb.2017.02009>

SANTOS, E. O.; MICHELON, M.; FURLONG, E. B.; DE MEDEIROS BURKERT, J. F.; KALIL, S. J.; BURKERT, C.A.V. Evaluation of the composition of culture medium for yeast biomass production using raw glycerol from biodiesel synthesis. Brazilian Journal of Microbiology, Rio de Janeiro, v. 1, p. 432-440, 2012. Doi: <https://doi. org/10.1590/S1517-83822012000200002>

SANTOS, E. O.; MICHELON, M.; GALLAS, J. A.; KALIL, S. J.; BURKERT, C. A. J. Raw glycerol as substrate for the production of yeast biomass. Internationl Journal of Food Engineering, Ghaziabad, v. 9, p. 413-420, 2013. Doi: <https://doi.org/10.1515/ijfe-2012-0248>
SILVA, G. P.; LIMA, C.; CONTIERO. Production and productivity of 1,3-propanediol from glycerol by Klebsiella pneumoniae GLC29. Catalisis Today, Amsterdam, v. 257, p. 259-266, 2015. Doi: <https://doi.org/10.1016/j. cattod.2014.05.016>

SISMAN, T.; GUR, O.; DOGAN, N.; OZDAL, M.; ALGUR, O. F.; ERGON, T. Single-cell protein as an alternative food for zebrafish, Danio rerio: a toxicological assessment. Toxicology and Industrial Health, London, v. 29, p. 792-799, 2012. Doi: <https://doi.org/10.1177/ $0748233712442711>$

SOUZA, K. S. T.; GUDINA, E. J.; SCHWAN, R. F.; RODRIGUES, L. R.; DIAS, D. R.; TEIXEIRA, J. A. Improvement of biosurfactant production by Wickerhamomyces anomalus CCMA 0358 and its potential application in bioremediation. Journal Hazard Material, Buffalo, v. 346, p. 152-158, 2018. Doi: <https://doi.org/10.1016/j.jhazmat. 2017.12.021>

SUNDH, I.; MELIN, P. Safety and regulation of yeasts intentionally added to the food or feed chains. Antonie Van Leeuwenhoek, Amsterdam, v. 99, p. 113-119, 2010. Doi: <https://doi.org/10.1007/s10482-010-9528-z>

TACCARI, M.; CANONICO, L.; COMITINI, F.; MANNAZZU, I.; CIANI, M. Screening of yeasts for growth on crude glycerol and optimization of biomass production. Bioresource Technology, Essex, v. 110, p. 488-495, 2012. Doi: <https://doi.org/10.1016/j.biortech.2012.01.109> 